\title{
Administrators' Perspectives on Strategies for Enhancing the Quality of Higher Education in Nigeria
}

\author{
Abiodun Oguntimehin ${ }^{1}$, Muyiwa Adeyemi ${ }^{1, *}$ \\ ${ }^{1}$ Faculty of Education (Olabisi Onabanjo University). [ ${ }^{*}$ Corresponding author. E-mail: \\ adeyemiaristotle@yahoo.com]
}

\begin{abstract}
The quality of education being provided in Nigeria is a source of concern to many stakeholders. This is particularly true of the higher education sub-sector of the country's education system. Thus, there is need for suggestions on ways through which these concerns may be addressed. This paper attempts to respond to this need by giving administrators' perspectives on strategies for enhancing the quality of education in the country. Starting with elucidation of the concept of quality in education, the paper propounds a tripartite model of quality in education. Using the model as an analytical point of departure, it discusses the gaps in quality assurance in Nigerian education and makes recommendations for improvement.
\end{abstract}

Keywords: Quality assurance; Education administration; Nigeria

\section{$1 \quad$ Introduction}

The quality of education being provided in Nigeria has been a source of great concern to all stakeholders in the industry. In recent years, the Academic Staff Union of Universities (ASUU) has on many occasions expressed her concern about poor state of Nigerian education particularly at the university level, in terms of poor quality of the graduates which is a consequence of poor academic environment.

The proliferation of privately sponsored higher educational institutions was a result of poor quality in the education system of the country at this level of education (Olayemi 2001). Evidence abounds for this low quality education and these factors are identified as follows: poor examination results; unemployment after schooling; unruly behaviour of school children; lack of seriousness on the part of students; poor work attitude of teaching personnel; poor teaching/learning environment. 
Negative views have been severally expressed in all the three levels of the country's education system. These views suggest that Nigerians are dissatisfied with the country's education system. Hence the need to embark on strategies for enhancing the quality in education which will lead to fruitful results in the system

\subsection{Concept of Quality Education}

The word quality connotes the degree of excellence of a product or service. Awokoya (1990) refers to quality in education as the relevance and appropriateness of the process to the needs of the community of the education offered. He points out that relevance varies from one level and type of education to another, since the objectives set for education at various levels vary.

Quality of education is relative and exists in degrees or standards. The quality of education like relevance of education varies from one education system to another and it is not static. It varies with time and societal expectations. It cannot be totally divorced from the objectives set out for education in any particular country, based on the needs of the people of the country (Adeyemi \& Nwosu, 2010; Egwurube, 1990, Olagboye, 2000). Obanya (2002) stated five important points to bear in mind about quality issues in education: They are as follows:

1. Quality can be observable and tangible and its effects can be easily felt.

2. Quality is not something you wait till the end of the process to see, but something which is (or should be) built into all phases of the development of an educational programmes

3. Quality is not a one dimensional construct, but a tripartite affair, with its inputs, process, and output dimensions.

4. Quality in education can be specifically targeted.

5. The educational development process can be systematically engineered to work towards quality.

Obanya (2002) goes further to illustrate the complexity of the issues which should be taken into consideration while working towards quality in education (Table 1). It is only a combination of quality inputs and quality processes that will lead to quality products (outcomes).

\section{Indices for Improving the Quality Education}

The following are some indicators of quality education. 
Table 1: Tripartite Model of Quality in Education

\begin{tabular}{|c|c|c|}
\hline Inputs & Processes & Outputs \\
\hline Society & $\begin{array}{l}\text { - Popular involvement in Implementation } \\
\text { - Societal acceptance of the programme }\end{array}$ & $\begin{array}{l}\text { Successful learning } \\
\text { - Acquisition of }\end{array}$ \\
\hline Policy & $\begin{array}{l}\text { - Adaptability to local conditions } \\
\text { - Democratic policy review practices }\end{array}$ & socially desirable \\
\hline $\begin{array}{l}\text { Management } \\
\text { Framework }\end{array}$ & $\begin{array}{l}\text { - Decentralization/devolution of powers } \\
\text { down to the grassroots level } \\
\text { - Empowerment and autonomy for operators }\end{array}$ & $\begin{array}{l}\text { non-intellectu } \\
\text { skills } \\
\text { - Continuing } \\
\text { interest in }\end{array}$ \\
\hline Curriculum & $\begin{array}{l}\text { - Responsive to societal and individual need } \\
\text { - Comprehensiveness: coverage of the three } \\
\text { h's (the head, the hands, and the heart) } \\
\text { - Adaptable to changing times, changing } \\
\text { needs, and changing conditions. }\end{array}$ & $\begin{array}{l}\text { learning } \\
\text { Full-fledged societal } \\
\text { support } \\
\text { - Permanent, } \\
\text { unqualified }\end{array}$ \\
\hline Teac & - Quantitatively adequate & $y$ 's interest \\
\hline & $\begin{array}{l}\text { - Adequately educated and professionally } \\
\text { prepared } \\
\text { - } \text { Adequately able to promote teacher-pupil } \\
\text { - Interaction to maximize learning } \\
\text { - Well-motivated through appropriate } \\
\text { welfare package, professional support and } \\
\text { opportunities for self-improvement. }\end{array}$ & $\begin{array}{l}\text { in the promotion } \\
\text { of Education } \\
\text { Motivated teaching } \\
\text { and educational } \\
\text { management force } \\
\text { - Teachers fully } \\
\text { devoted to }\end{array}$ \\
\hline Infrastr & $\begin{array}{l}\text { - Quantitatively, aesthetically and } \\
\text { spaciously adequate } \\
\text { - Learner and teacher friendly } \\
\text { - Integrated pedagogical space of } \\
\text { classrooms-laboratories-libraries, toilets, } \\
\text { water, farms-workshops, etc. }\end{array}$ & $\begin{array}{l}\text { continuous self- } \\
\text { improvement for } \\
\text { concerted } \\
\text { promotion of } \\
\text { Education } \\
\text { Self-regenerating } \\
\text { educational system }\end{array}$ \\
\hline Materials & $\begin{array}{l}\text { - Quantitatively adequate } \\
\text { - User friendly, easily exploitable and } \\
\text { challenging to both teachers and learners } \\
\text { - Mix of print-audio-aural materials } \\
\text { - Closely related to curriculum goals }\end{array}$ & $\begin{array}{l}\text { for a self-regenerating } \\
\text { society } \\
\text { - Committed } \\
\text { society, a critical } \\
\text { mass of }\end{array}$ \\
\hline Funds & $\begin{array}{l}\text { - Quantum (adequacy) of funding } \\
\text { - Targeting funds to those things that will } \\
\text { really make a difference } \\
\text { - Prompt releases of funds } \\
\text { - Prudent application of funds. }\end{array}$ & $\begin{array}{l}\text { productive/creati } \\
\text { ve citizens an } \\
\text { education system } \\
\text { that goes on } \\
\text { improving. }\end{array}$ \\
\hline
\end{tabular}

Source: Obanya (2002)

\subsection{Teaching Personnel Training and Development}

The need for quality education informed the special attention to teaching personnel continuous training and development through various programmes, so as to update their knowledge and improve their skills. The main purpose of teacher continuing education is to improve education in all its ramifications. 
The National Policy on Education (FRN, 2004) places emphasis on teacher education. The policy specifies that teacher education is aimed at:

1. Producing highly motivated, conscientious and efficient classroom teachers for all levels of the educational system.

2. Encouraging further the spirit of enquiry and creativity in teachers

3. Helping teachers to fit into the social life of the community and society at large and to enhance the commitment to national objectives.

4. Producing teachers with the intellectual and professional background, that is, adequate for their assignment and to make them adaptable to any changing situation not only in the life of the country, but in the wider world.

5. Enhancing teacher commitment to the teaching profession.

All these objectives no doubt go a long way in determining the quality of education the in country. Effective teacher training programme will bring about quality in education. In the words of Adeboyeje (2000), using a functional notation, quality education is said to be a function of effective and adequate teacher training and preparation. He postulates that the correlation between the concepts may be expressed as $\mathrm{Qe}=f(\mathrm{Tt})$ where: $\mathrm{Qe}=$ quality education; $(\mathrm{Tt})=$ Teacher Training; and $f=$ functional notation.

Qe is a dependent variable, while $\mathrm{Tt}$ is an independent variable. Before a qualitative education can be achieved, the teachers must undergo adequate and effective training programmes: Mgbako-Ezennia (1992) cited in Adeboyeje (2000) and Adeyemi (2007) states that the ability of the teacher is crucial determinant of the quality of education in any society... teachers with bare competence are not likely to help the youths meet the challenges of modern living.

In achieving quality education through effective teacher training and development, the following suggestions can be taken into consideration:

1. There is a need to harmonize the internal and external criteria of quality (i.e. raising standard of excellence of the teacher education programme).

2. An effective supervisory system should be injected into the education system

3. Programmes of public enlightenment and teacher training aimed at developing the awareness and understanding on the central place of the teacher as a great influence on learning should be mounted by the government.

4. The problem of acute shortage of qualified teachers in sciences, mathematics and other various technical disciplines should be solved by motivating which could be done through bursary/scholarship awards.

5. Teaching performance of individual teachers should be ascertained and improved through various in-service strategies such as workshops, seminars, 
conferences, short/long vacation courses, which should form part of the promotion criteria.

A clear and firm statement of teaching personnel development policy is highly essential; it should be formally approved for use by the Ministry of Education. Each state can have "State Development Board', which will be charged with the responsibility of indicating what, should be done regarding the development of teaching staff.

\subsection{Training of Educational Administrators}

The educational administrator works with and through people to accomplish the educational goals. Hence it is imperative for educational administrators to be sensitive to human factor so as to bring about quality in education. It is a fact that you cannot give what you do not have. The dynamic nature of life generally, and that of education in particular calls for personnel that are current in trends and issues in educational policies, aims and objectives which are designed to advance knowledge.

Human beings are complex in nature, making the job of administration very sensitive, thus anyone who is to be entrusted in administrative post must be well trained in theories and principles and in addition to these, must be able to apply them practically. The point being stressed here is that educational administrators need some professional preparation so as to function effectively as school leaders, which will invariably lead to quality education.

The identification of training needs of educational administrators could be determined by

Examining the critical abilities needed by educational leaders. As people who help in determining education policies, participate in the implementation of policies, and are in charge of coordinating, controlling and supervising organizational activities, they are expected to possess certain knowledge, skills and abilities (Nwagwu, 1990: P.9).

Nwagwu (1990) citing Love (1986) identified such abilities as to work with people; think analytically persuade and convince others; communicate effectively; take appropriate and timely decisions; see broad relationships; be diplomatic within a political environment; and organize and control a management system.

It has been observed that all educational administrators do not have competence in all the identified abilities (Nwagwu 1990). Therefore, for each target group to be trained, we should identify which abilities are the educational administrators deficient in, and then focus training on these. Ogundare (2005) identifies some techniques for determining training needs. They are: 
1. Requests made by top administrators for special training for less experienced managers.

2. Recommendations of management audit panels on the type of training needed by identified administrators.

3. Interviewing managers themselves to find out their specific training needs.

4. Analysis of the skills needed for the job of managing the organization.

5. Group conferences at which management training needs are discussed together with organizational needs.

6. The use of tests or examinations in order to determine deficiencies in the skills and abilities of managers.

7. The use of questionnaires to survey the requirements of administrators for training purpose.

8. Studying the personal files and records of administrators or those being proposed for training.

9. Performance ratings of managers by either their superior officers or their subordinate officers.

10. Reports prepared by supervisors or inspector who interact frequently with the administrators.

11.The future needs of the organization and the type of management staff needed for changes and innovations.

The training does not necessarily need to e specialized or that all educational administrators should possess doctorate, master or bachelor degrees in educational administration. It is just to ensure that the basic training exists in the principles and practice of educational management. The training can be organized by the ministry of education or any authorized body, saddled with supervision/inspection of schools, or the universities/colleges of education. The National Institute for Educational Planning and Administration, Ondo, was established in 1992, with the mandate to develop "a critical mass of education sector planners and managers for the effective planning and management of the education system through capacity building, continuous training, monitoring and information dissemination" (NIEPA 1992). Specifically, the objectives of the institute are:

1. The provision of specialized and relevant planning skills for Nigerian;

2. The provision of educational management and development activities like training, consultancy service, research and development;

3. The continuing professional development of practitioners through planning and implementing training programmes directed at equipping and enhancing the competence of serving officers in educational planning and administration;

4. The organization and management of programmes of consultancy services to the educational system; 
5. The projection and forecast of future trends in educational management and practices and their relevance to education in Nigeria;

6. The monitoring and review of regional and world trends in educational management and planning practices;

7. Serving as a resource centre and network of information in educational planning in Nigeria.

The time of training should be during the short or long vacations. Assessment of participants should be conducted and graded certificates should be awarded. Professionally qualified educational planners and administrators equipped with modern technologies of educational management should be in charge of educational organizations.

\subsection{Funding}

Of all the various problems facing education in Nigeria, none is as persistent and virulent as the insufficient funding. A vital determinant of assuring quality in education is funding. In the words of Coombs (1968) money is an absolutely crucial input in any educational system. It provides the essential purchasing power with which education acquires its human and physical inputs: With too little money, education can be helpless. With an ample supply, its problems become more manageable, even though they do not vanish.

Hinchliffe (2003) submitted that the Federal government expenditures on education between 1997 and 2001 are below 10\% of its overall expenditures. The shares have varied between 9.9 and $7.6 \%$ as shown on Table 2, and the trend has been largely downward. This submission of Hinchdiffe is in sharp contrast to the UNESCO's recommendation of $26 \%$ share for expenditure on education.

Table 2: Federal Government Expenditure on Education as Share of Total Federal Government Expenditure (1997-2002, \%)

\begin{tabular}{lllllll}
\hline & 1997 & 1998 & 1999 & 2000 & 2001 & 2002 \\
\cline { 2 - 7 } Recurrent & 12.3 & 12.0 & 11.7 & 9.4 & 9.5 & 9.1 \\
Capital & 6.1 & 7.5 & 5.0 & 8.5 & 6.0 & 6.0 \\
Total & 9.9 & 9.6 & 9.0 & 9.0 & 7.6 & 8.0 \\
\hline
\end{tabular}

Source: Herbert (2002) Hinchliffe (2003) and cited by Adeyemi and Nwosu (2010)

The sampled state governments' total expenditures on education and its distribution across levels vary considerably (see Tables 3 and 4). Table 4 indicates that all the states selected for the study have more than $50 \%$ of the allocation for secondary education except Oyo State which has just 37.6\%. The 
implication of these allocations especially at the federal level cannot bring about quality in education.

Table 3: Share of State* Government Education Expenditure (\%)

\begin{tabular}{llllll}
\hline State & 1995 & 1996 & 1997 & 1998 & 1999 \\
\hline Enugu & 20.1 & 15.6 & 20.2 & 14.8 & 17.0 \\
Rivers & 25.0 & 18.4 & 16.0 & 19.2 & 9.2 \\
Borno & 13.3 & 16.6 & 9.9 & 21.2 & 12.6 \\
Oyo & 14.6 & 12.6 & 13.0 & 11.4 & 11.6 \\
Benue & 34.6 & 28.1 & 24.4 & 21.5 & 29.9 \\
Anambra & 28.0 & 28.9 & 33.5 & 16.0 & 27.4 \\
Niger & 15.3 & 17.3 & 32.4 & 16.4 & 27.5 \\
Ekiti & & & 35.6 & 22.9 & 27.1 \\
Jigawa & & & 23.0 & 21.0 & 16.8 \\
Kano & & & & 11.0 & 13.8 \\
Plateau & & & & 21.7 & 19.0 \\
Lagos & & & & & 24.8 \\
Median & 20.1 & 17.3 & 23.0 & 19.2 & 18.0 \\
\hline
\end{tabular}

*Selected States

Source: Herbert (2002) Hinchliffe (2003) and cited by Adeyemi and Nwosu (2010)

Table 4: Share of State* Government Education Expenditure by Educational Level $(1998, \%)$

\begin{tabular}{lllll}
\hline State & Primary & Secondary & Tertiary & University \\
\hline Enugu & 17.0 & 52.7 & 30.3 & 0.0 \\
Rivers & 9.7 & 50.6 & 21.4 & 18.3 \\
Borno & 5.0 & 69.1 & 25.8 & 0.0 \\
Kano & 9.2 & 66.3 & 24.5 & 0.0 \\
Plateau & 3.3 & 83.9 & 12.8 & 0.0 \\
Benue & 11.9 & 50.2 & 15.3 & 22.2 \\
Ekiti & 10.4 & 66.2 & 13.0 & 10.4 \\
Niger & 13.8 & 65.8 & 16.6 & 3.8 \\
Oyo & 23.1 & 37.6 & 27.5 & 11.8 \\
Average & 11.4 & 60.3 & 20.8 & 7.4 \\
\hline
\end{tabular}

*Selected States

Source: Herbert (2002) Hinchliffe (2003) and cited by Adeyemi and Nwosu (2010)

The problem of financing education has become so critical that it continues to re-echo in public lectures, seminars, conferences and workshops, even on television and radio programmes. The continued closure of public schools, arising out of teachers 'industrial action over the last four to five years, were the aftermaths of inadequate funding. It is not an exaggeration to state that education system is experiencing financial starvation. Many tertiary 
institutions, especially university have been forced to skip an academic session or two due to strike actions embarked upon by Academic Staff Union of Universities (ASUU).

The estimates of government education expenditure in Nigeria as a share of GDP and total government expenditure when compared with other sub-Saharan African countries are relatively low. UNESCO's World Education Report 2000 presents the data for nineteen (19) countries across sub-Saharan Africa for 1996. The average share of GDP was $4.7 \%$ and of government expenditure was $19.6 \%$. In both cases, the measures of educational expenditures for Nigeria are $2.3 \%$ and $14.3 \%$ respectively.

The shares across education levels in Nigeria when compared with eighteen (18) other sub-Saharan countries in 1996, the shares were $48 \%$ primary, $31 \%$ secondary and $21 \%$ tertiary (UNESCO, 2000). The allocations to primary schooling were significantly lower in Nigeria and those to tertiary education were significantly higher. However, Obanya (2002), opinionated that the emphasis should not merely be on more funds, but should be more on improving the funding process. He therefore, suggested the following:

1. A more rigorous analysis on what should be funded, with a strong emphasis on those things that are likely to have positive, multiplier effects on Education;

2. Programming activities and projects to rhyme with the availability of funds;

3. Dwelling more and more on the cost-effectiveness of educational programme;

4. Improved management of available funds, including a very meticulous check on corruption and all cases of misappropriation of funds; and

5. Diversifying the source of funding, i.e. going beyond government to other sources.

\section{$3 \quad$ Curriculum Planning and Implementation}

According to Daramola (1995), the planning of a curriculum is:

... a phase of curriculum whereby goals of the curriculum to be developed are clearly highlighted by a well constituted body depending on the political system of the society in which the curriculum is to be used (Daramola, 1995: pg. 27).

The experiences to be acquired are guided by:

1. The philosophical framework of the society;

2. The political system of the society;

3. The financial standing of the society; and 
4. The availability of appropriate personnel and facilities for good curriculum design.

In Nigeria, however, the problem of achieving the goals and objectives of quality in education is not that of planning but implementation. In recognition on this fact, Daramola (1995) stated that "our experience and expertise to tackle curriculum development in many subject areas are recognized but our major problem lies with implementation". Suffice to say therefore that no education system can rise above the planned and implemented curriculum, just like the calibre of teachers in the education system. To ensure quality in education, the curriculum process must have in-built mechanisms. The following suggestions as given by Ojadele (2000) will help to enhance the quality education in Nigeria through curriculum planning and implementation:

1. Efforts should be made to make learning experiences and the contents of the curriculum to be relevant to the needs of the Nigerian society, as well as to suit the age, experience and aspirations of the learners. This is to satisfy the principles of suitability and relevance not only on the part of the learners but the community which the curriculum is expected to serve.

2. For curriculum to achieve quality education, its planning and implementation must involve across-section of the people who are stakeholders in it. This will include teachers, learners, parents, trade unions, religious bodies, educational administrators, professional organizations, etc. The inputs of the aforementioned bodies and organizations will help enrich the curriculum so designed and guarantee quality education. At the implementation stage for instance, involvement of parents is crucial since they are expected to be actively involved in the education process of the children/wards through encouragement and provision of educational material needs.

3. Curriculum should pass through all the necessary planning and implementation stages for quality control. Also the problems encountered at each stage should be noted and rectified before moving to the next stage.

4. In ensuring quality control in curriculum implementation, the Quality Control/Inspectorate Division/Curriculum Implementation Unit at Federal and State Ministries of Education have crucial roles to play in ensuring that the curriculum is implemented in line with the stated aims, goals and objectives, particularly at the school level. To effectively achieve these goals, Inspectors of Education should be provided with necessary tools that will help them to reach their goals.

5. Evaluation assists in achieving effectiveness in curriculum implementation. It shows how effective the selected learning experiences and contents are in achieving the stated goals and objectives. It allows feedback into the system and provides opportunities for corrections to be effected early enough, 
particularly at the planning and implementation stages of the curriculum. Thus, it is only through evaluation that a curriculum can be judged as suitable and of good quality in achieving high standard.

6. Economic consideration is very important in the choice of a curriculum. It is equally important that economy should not be used as a factor to reduce the qualitative goal of education. The 6-3-3-4 system of education was introduced in 1981 with the hope of enriching the quality of Nigerian education. The education system is on the verge of collapse due to shortage of funds and faulty implementation among other teething problems.

7. Political considerations cannot be divorced from any system of education. However, while political consideration should continue to be a good factor of note in curriculum planning and implementation, it should not be allowed to have negative effect on the quality of curriculum in particular and education in general.

8. Effective curriculum planning and implementation leading to quality education can only be guaranteed when adequate data are collected, analysed and used appropriately for various decisions concerning curriculum, its planning as well as its implementation.

9. It is important that to guarantee quality education, curriculum planning and its implementation should be revised continuously to accommodate social, cultural, historical, political and economic factors.

In addition, Obanya (2002) opines that to make education relevant in Nigeria requires a strong emphasis on curriculum enrichment which should include

1. General education (general exposure to broad fields of knowledge and ways of knowing) as foundation for more specialized education;

2. Teaching/learning methods that dwell more on developing analytical /communicative/ manipulative/ finding-out skills and on logical (verbal and quantitative) reasoning i.e. the skills needed for life-long learning;

3. Science and technology (including information technology at all levels) with a particular focus on the methods and processes of science and technology;

4. A complete de-examination of the system, in favour of learning for mastery;

5. A close link between school learning and the goings-on in the wider society and most especially in the world of work; and

6. Teaching/learning materials that go beyond mere textbooks to materials from the wider society.

\subsection{Enabling Environment for Teaching and Learning}

Education is basically about transmitting desirable skills and attitude to help individuals fit into the society. Therefore, Obemeata (1995)'s findings that 
there was shortage of textbooks, audio-visual materials and science equipment in education institutions is disturbing.

The overcrowded classrooms in tertiary institutions make teacher-learners interactions practically impossible. In some institutions where laboratory facilities are available, they are quite obsolete and students are not exposed to practical skills. The reading culture now lacking in our education system is traceable to non-availability of current books, journals, etc. in the school libraries. The available school plant facilities are eye sores. To enhance quality education, these educational resources have to be of appropriate quality and quantity which will promote meaningful teaching and learning. Considerable efforts have been put in place in the production of non-text materials by organizations like National Education Technology Centre (NETC) and the Science Materials Development Centres in Awka, Akure, Enugu, Ijanikin, etc. The government should motivate and monitor these organizations so as to be more widely used and more impactful at the school level through increased patronage by all governments of the federation (Obanya 2002). It is not an overstatement that the "quality (and quantity) of infrastructural facilities available in an educational system influence the output of the system" (Fadipe 2000). The facilities which include the classrooms, offices, libraries, laboratories, conveniences and other buildings as well as the chairs/desks and tables are good determinants of quality education.

However, it is not enough to have these resources available at resources centres, or in schools. Authorized government agencies should monitor to see that the resources are equitably distributed and judiciously utilized. The schools too should be encouraged to get these resources and to monitor their utilization.

\subsection{Community Involvement in Education}

The strengthening of school-community interaction so as to bring about the desired quality in education is a task that has to be accomplished. The link should not be linked to a particular level of education system. Ojedele (1998), Ejieh (1990), among other educationists have discovered in their various studies that the effectiveness of education system would be improved through greater cooperation with community leaders, with particular reference to the parents. Hoyle (1975) research, cited by Ojedele (1998), indicates that teachers see parental support as improving their effectiveness and satisfaction.

Olaniyi (2000) stated that school-community relationship is a two way process, a two way flow of ideas and activities, which provides the basis for mutual understanding and effective teamwork. In the words of Ejieh (1990), "increased parental and community involvement in school affairs is desirable in our quest for the qualitative development of education system, especially in these days of continued cut backs in the budgetary allocation for education. 


\section{Conclusions}

Without quality, education becomes wastage and even a threat to the individual in particular and the society in general. For education to be of quality, it must be functional in all its ramifications i.e. it must be functional in content, context and in both internal and external operations. A qualitative education is a type that will transform economic, social, political, technological and cultural structures of the nation. In addition to the suggestion given to improve the quality of education, the following should also be taken into consideration by the education policy makers/implementers and administrators.

1. Quality improvement in educational system must not be a fad; it must be a long term of continuous effort;

2. While educational top-management commitment is of great importance, everybody in education industry must also be committed to quality;

3. Quality control should be done at crucial stages, set quality/standard criteria for each important stage.

4. Quality improvement plan is not enough; provisions must be made for its proper implementation.

5. Education is a priority which must be considered before all other priorities because it is the cornerstone for national development, therefore it should be qualitative.

\section{References}

Adeboyeje, R. (2000). Teacher training and utilization for quality education in Nigeria. In J. Fadipe and P. Ojedele, (Eds.) Management of Nigerian Education: Personnel administration and quality in education. Published for NIEPA, Ondo: Daily Graphics, Ibadan.

Adeyemi, M., Nwosu, J. (2010). Universal Basic Education -implications of Facilities Provision on Primary Education in Nigeria. Ibadan: Franc-ola Publishers.

Adeyemi (2007) and this under the references would read: Adeyemi, M (2007). Impact Assessment of Universal Basic Education Facilities on Primary School Performance Variables in Ogun State. Unpublished Thesis, Olabisi Onabanjo University, Nigeria.

Awokoya, O. (1990). Perspectives of quantities and qualities in Nigerian education. In K. Ajayi and T. Ajayi (Eds.) News Perspectives in Nigerian education, Ibadan: Vantage Publishers.

Bellamy, C. (1999). The State of the World's Children-UNICEF. 
Coombs, P. (1968). The World Educational Crisis: A systems analysis. New York: Oxford Press.

Daramola, S. (1995). Curriculum Development in Schools. Ilorin: Lekan Printing Press.

Egwurube, B. (1990). "Educational Standard: its Meaning, Scope and Perspectives", Education Today 3(3).

Ejieh, M. (1990). The school, the local community and quality in education: Some implication for Educational Planning. In Udoh, S. and Akpa G. (Eds.) Management for quality education in Nigeria, Ehindero Nig. Ltd., Jos.

Fadipe, J. (2000). Efficiency indicators for quality control in Nigerian school system. In J. Fadipe, and P. Ojedele (Eds.) Management of Nigerian Education Personnel Administration and Quality in Education. Ibadan: Daily Graphics.

Hinchliffe, K. (2003). Public expenditures on education in Nigeria: Issues, estimates and some implications- African Region Human Development Working Paper Series-World Bank Report.

Nwagwu, C. (1990). Improving the performance of educational system through professional training of educational administrators. In S. Udoh and G. Akpa (Eds.) Management for Quality Education in Nigeria. Jos: Ehindero Nig. Ltd.

Obanya, P. (2002). Revitalizing education in African. Ibadan: Stirling-Horden Publishers.

Obemeata, J. (2000). Infrastructural and Manpower Needs of Secondary Education in Nigeria: Key note address at All Nigeria Conference of Principals of Secondary Schools (ANCOPSS), Ikenne, Ogun-State Branch, 14th-17th Nov.

Ogundare, S. F. (2005). Nigeria's Universal Basic Education in the Context of Education For All (EFA) and the United Nations Millennium Development Goals $(M D G S)$. Paper presented at the UBE Training Workshop for Primary School Teachers in Oyo State 2005 UBE programme, December 13-16.

Ojedele, P. (1998). Parental school visitation as a factor affecting the performance of secondary school in Oyo State of Nigeria. Journal of Applied Research in Education. 3(1). Department of Educational Admin., University of Lagos.

Olagboye, A. (2000). Institutional management for quality control of education in Nigeria. In J. Fadipe and P. Ojedele (Eds.) Management of Nigerian Education: Personnel Administration and Quality in Education. Ibadan: Daily Graphics.

Olaniyi, W. (2000). School community relations in the 21 st century. In J. Fadipe and E. Oluchukwu..(Eds.) Educational Planning and Administration in Nigeria in the 21 st Century. Ibadan: Daily Graphics. 
Olayemi, A. (2001). Closure of private schools. Nigerian Tribune. Thursday October 11, pg. II.

UNESCO (2000). World Education Report, Paris: UNESCO. 